\title{
Mycobiota of Commercially Available Triphala Powder: A Well Known Dietary Supplement of Indian System of Medicine
}

\author{
Sushil Sharma, ${ }^{1,2}$ Madhu Gupta, ${ }^{1}$ and Rekha Bhadauria ${ }^{1}$ \\ ${ }^{1}$ Mycology and Plant Pathology Laboratory, School of Studies in Botany, Jiwaji University, Gwalior, Madhya Pradesh 474011, India \\ ${ }^{2}$ Amity Institute of Biotechnology, Amity University, Gwalior, Madhya Pradesh 474005, India \\ Correspondence should be addressed to Rekha Bhadauria; rekhabhadauria@yahoo.com
}

Received 12 June 2013; Revised 7 September 2013; Accepted 8 December 2013; Published 20 January 2014

Academic Editor: Lei Cai

Copyright (c) 2014 Sushil Sharma et al. This is an open access article distributed under the Creative Commons Attribution License, which permits unrestricted use, distribution, and reproduction in any medium, provided the original work is properly cited.

\begin{abstract}
Sixty samples, categorized on the basis of manufacturers, were analyzed during the study. A total of 16 fungal species, belonging to 7 different genera, were isolated from the collected samples. Aspergillus was recorded as the most dominant genus with 9 species, namely, A. niger, A. carbonarius, A. luchuensis, A. fumigatus, A. flavus, A. nidulans, A. terreus, A. ochraceous, and A. wentii. A. niger was the most predominant species with frequency of occurrence of $63.33 \%$. A large variation in fungal load and diversity was observed among the samples of different manufacturing categories. The percent moisture content and $\mathrm{pH}$ of samples were directly related to the extent of contamination. Samples with low $\mathrm{pH}$ and high moisture content were more contaminated. The higher incidence of $A$. niger (74.36\%) was observed among the triphala powder of all manufacturing categories. Detection of ochratoxin producing fungi in triphala powder may pose a serious risk of ochratoxin production. Thus, there is an urgent need to enforce quality standards and regulation to minimize the fungal contamination to the globally expectable limit.
\end{abstract}

\section{Introduction}

Triphala powder is a world widely used herbal formulation of Indian system of medicine. It is easily available in the global market as a dietary supplement. It is a powdered mixture of shade dried fruit pulp of three important myrobalans, that is, Emblica officinalis Gaertn., Terminalia bellerica Roxb., and Terminalia chebula Retz. in equal proportion. It is considered as an important rejuvenating formulation in Ayurvedic system of medicine. The recipe for this formulation is described in the ancient books on Ayurveda (most prevalent Indian system of medicine), the "Charak Samhita" and "Susruta Samhita" (ancient Ayurvedic literature), which date back to 1500 BC [1]. A popular folk saying in India is "No mother? Do not worry so long as you have triphala." This means triphala can care for the internal organs of the body as a mother cares for her children. It is also mild, nonhabit forming, the safest, and most strengthening laxative and purgative formulation, hence recommended for all age groups.

Triphala encompasses the phytochemical constituents of all the three ingredients. Tannins, phenolics, flavonoids and ascorbic acid have been reported as major phytochemical constituents from this formulation [2, 3]. Ayurvedic doctors and herbal practitioners recommend this formulation for the treatment of the constipation, weight loss [4], enhancement of intelligence, strength, youth, luster, sweetness of voice, and vigor [1].

However, being a plant based formulation; it is highly prone to fungal contamination. Although products available in markets are packed in air tight containers but still they harbor various types of fungal species. Research has shown a steady and marked presence of fungi in various herbal formulations and their raw materials including triphala [514]. High incidence of fungal contaminants may deteriorate the quality of the products by degradation of the phytoconstituents, thereby reducing the potency and shelf life of the drug and rendering it unfit for the consumption $[12,15]$. Besides the deteriorative potential, the presence of fungi in herbal formulations is also a public health issue due to the possibility of mycotoxin production. Various species of Aspergillus, Penicillium, and Fusarium are involved in the production of these toxic secondary metabolites, which have mutagenic, carcinogenic, hepatotoxic, nephrotoxic, and teratogenic effects upon human and animals [16]. In earlier 
studies, Gautam and Bhadauria $[13,14,17]$ have detected the aflatoxins in triphala powder samples.

Moisture content and $\mathrm{pH}$ of the samples are two main abiotic factors that govern the fungal contamination of the materials. Currently, there are no data available on the relationship between $\mathrm{pH}$, moisture content of the formulation, and storage time with fungal load and diversity. Therefore, this experiment was carried out to study the mycobiota of triphala powder and influence of the $\mathrm{pH}$, moisture content of the formulation, and storage time on the extent of fungal contamination.

\section{Materials and Methods}

2.1. Experimental Sample. The samples of all brands of triphala powder were randomly purchased from the retailers and herbal practitioners of the Gwalior district (Madhya Pradesh, India) in original packing during the years 2010 and 2011. Collected samples were categorized on the basis of their manufacturers into multinational, regional, local, and herbal practitioner categories. A total of 60 samples of triphala powder were collected during the study. Out of which 15 were of multinational manufacturers, 32 of regional manufacturers, 9 of local manufactures, and 4 from herbal practitioners. Samples of the multinational and regional manufacturers were packed in airtight containers weighing 50 to $100 \mathrm{~g}$, whereas samples from local manufacturers and herbal practitioners were collected in UV sterilized polyethylene bags. After noting product related details like date of manufacturing, batch number, expiry date, date of collection, and storage time (date of Mfg to date of collection), collected samples were stored at $25 \pm 2^{\circ} \mathrm{C}$ for further study. The storage period of collected samples varied from 2 to 20 months and samples with more than this storage period were not included in this study.

2.2. Measurement of $p H$. $5 \%$ suspension of each sample was prepared in distilled water and constantly shaken for one hour. $\mathrm{pH}$ of the suspension was measured using a digital $\mathrm{pH}$ meter. Each sample was analyzed in triplicate.

2.3. Analysis of Total Moisture Content. The moisture content of the triphala powder samples was determined using the standard method [18]. Two grams of triphala powder, taken in previously dried and tarred flat weighing bottle in triplicate, was oven dried at $105^{\circ} \mathrm{C}$ until two consecutive weighing do not differ by more than $5 \mathrm{mg}$. Total moisture content was calculated by the following formula:

$$
\% \text { moisture content }=\frac{\text { Initial weight }- \text { Final weight }}{\text { Initial weight }} \times 100 \text {. }
$$

2.4. Enumeration of Mycobiota. Different fungi were isolated from the triphala powder samples by pour plate technique, using Czapek Dox agar media ( $\mathrm{pH}$ 7.3) supplemented with chloramphenicol. Under aseptic conditions, $1 \mathrm{~g}$ sample was suspended in $9 \mathrm{~mL}$ of sterilized distilled water and serial dilutions were made. One $\mathrm{mL}$ aliquots from appropriate dilution were poured in sterilized petri plates (in triplicate) and appropriate amount of media was added and mixed well. After solidification, plates were incubated at $25 \pm 2^{\circ} \mathrm{C}$ for 7 days and colony forming units per gram $(\mathrm{CFU} / \mathrm{g})$ of fungi were calculated using the following formula:

$$
\mathrm{CFU}=N \times 10^{-n}
$$

where $N$ is total number of colonies and $n$ is dilution.

After seven days of incubation period, plates were examined and pure culture of each fungal isolate was prepared for identification purpose.

2.5. Fungal Identification. Isolated fungal species were identified on the basis of their cultural characteristics/colony morphology and microscopic characteristics as described by Thom and Raper [19], Gilman [20], Barnett [21], Jamaluddin et al. [22], Samson et al. [23, 24].

2.6. Statistical Analysis. Pearson's correlation coefficient was performed to test the correlation between various factors by using Minitab 16 software.

\section{Results}

3.1. Mycobiota of Triphala Powder. A high level of fungal contamination was observed in triphala powder samples. As Table 1 shows, the majority of samples were contaminated with various types of fungal species with varying degree of frequency of occurrence. Out of 60 samples, 45 (75\%) were found to possess one or other types of fungal species, and about $68 \%$ samples were with fungal load of $>10^{3} \mathrm{CFU} / \mathrm{g}$ (data not shown). A total of 16 fungal species belonging to generas Aspergillus, Penicillium, Alternaria, Curvularia, Fusarium, Chaetomium, and Rhizopus in the range of $10^{2}-10^{5} \mathrm{CFU} / \mathrm{g}$ were isolated during the study (data not shown). Aspergillus group was isolated as the most dominant genus with 9 species, and with an incidence of $96 \%$. Nigri section represents $88 \%$ of Aspergillus species, with A. niger as most prevalent species isolated from $63.33 \%$ of samples, and has a share of $87 \%$ among members of Nigri section and $74.36 \%$ share among all the isolated fungal species (data not shown). Section Fumigati was the second most dominant genus represented by $A$. fumigatus, isolated from $26.66 \%$ of the samples, followed by A. flavus of Flavi section with presence in $20 \%$ of the samples. All the contaminated samples were found to harbor one or another species of Aspergillus. Some other dominant species were $A$. carbonarius, $A$. nidulans, and $A$. luchuensis with $16.66 \%, 10 \%$, and $8.33 \%$ of frequency of occurrence, respectively. Other less abundant fungal contaminants includes A. terreus, A. ochraceous, $A$. wentii, Penicillium citrinum, $P$. chrysogenum, Curvularia lunata, and Alternaria alternata. Species of Fusarium, Rhizopus, and Chaetomium were present only in few samples, not exceeding $7 \%$ of the frequency of occurrence. Three fungal species, namely, $A$. wentii, species of Chaetomium and Rhizopus, were isolated from one sample only.

Table 2 shows the manufacturing category-wise detail of mycobiota of triphala powder. In case of the samples of 
TABLE 1: Frequency of occurrence and total incidences of species, isolated from the various categories of triphala powder.

\begin{tabular}{|c|c|c|c|c|c|c|c|c|c|c|}
\hline \multirow{3}{*}{$\begin{array}{l}\text { Sample type (no. of sample.) } \\
a / b^{\mathrm{e}} \\
\text { Fungal sp. }\end{array}$} & \multirow{2}{*}{\multicolumn{2}{|c|}{$\begin{array}{c}\text { Overall (60) } \\
45 / 60\end{array}$}} & \multirow{2}{*}{\multicolumn{2}{|c|}{$\begin{array}{c}\text { Mult. }^{\text {a }}(15) \\
11 / 15\end{array}$}} & \multirow{2}{*}{\multicolumn{2}{|c|}{$\begin{array}{c}\text { Reg. }^{\text {b }}(32) \\
25 / 32\end{array}$}} & \multirow{2}{*}{\multicolumn{2}{|c|}{$\begin{array}{c}\text { Loc. }^{c}(9) \\
7 / 9\end{array}$}} & \multirow{2}{*}{\multicolumn{2}{|c|}{$\begin{array}{c}\text { Herb. } \text { P. }^{\mathrm{d}}(4) \\
2 / 4\end{array}$}} \\
\hline & & & & & & & & & & \\
\hline & $\mathrm{FO}^{\mathrm{f}}(\%)$ & $\mathrm{TI}^{\mathrm{g}}(\%)$ & FO (\%) & TI (\%) & FO (\%) & TI (\%) & FO (\%) & TI (\%) & FO (\%) & $\mathrm{TI}(\%)$ \\
\hline Aspergillus niger & 63.33 & 74.36 & 66.66 & 84.75 & 59.37 & 63.90 & 77.77 & 78.39 & 50 & 71.66 \\
\hline A. carbonarius & 16.66 & 8.82 & 26.66 & 10.96 & 12.5 & 6.95 & 11.11 & 4.93 & 25 & 12.5 \\
\hline A. luchuensis & 8.33 & 2.20 & 6.66 & 0.23 & 12.5 & 4.82 & $\mathrm{ND}^{\mathrm{h}}$ & $\mathrm{ND}$ & ND & $\mathrm{ND}$ \\
\hline A. flavus & 20 & 4.85 & 6.66 & 0.34 & 25 & 9.30 & 11.11 & 2.46 & 50 & 7.5 \\
\hline A. fumigatus & 26.66 & 2.84 & 20 & 1.03 & 28.12 & 4.03 & 22.22 & 3.08 & 50 & 6.66 \\
\hline A. terreus & 5 & 1.02 & ND & ND & 9.37 & 2.35 & ND & ND & ND & ND \\
\hline A. nidulans & 10 & 2.20 & 20 & 1.84 & 9.37 & 3.25 & ND & ND & ND & ND \\
\hline A. ochraceous & 3.33 & 0.29 & ND & ND & 6.25 & 0.67 & ND & ND & ND & $\mathrm{ND}$ \\
\hline A. wentii & 1.66 & 0.19 & ND & ND & ND & ND & 11.11 & 2.46 & ND & $\mathrm{ND}$ \\
\hline Penicillium citrinum & 3.33 & 0.44 & $\mathrm{ND}$ & ND & 6.25 & 1.0 & ND & $\mathrm{ND}$ & ND & $\mathrm{ND}$ \\
\hline P. chrysogenum & 3.33 & 0.53 & 6.66 & 0.57 & 3.12 & 0.67 & ND & ND & ND & ND \\
\hline Alternaria alternata & 6.66 & 0.39 & ND & ND & 12.5 & 0.89 & ND & ND & ND & $\mathrm{ND}$ \\
\hline Curvularia lunata & 6.66 & 0.44 & ND & ND & 3.12 & 0.11 & 22.22 & 3.70 & 25 & 1.66 \\
\hline Fusarium sp. & 6.66 & 0.53 & 6.66 & 0.23 & 3.12 & 0.67 & 22.22 & 4.93 & ND & ND \\
\hline Chaetomium sp. & 1.66 & 0.78 & $\mathrm{ND}$ & ND & 3.12 & 1.25 & ND & $\mathrm{ND}$ & ND & $\mathrm{ND}$ \\
\hline Rhizopus sp. & 1.66 & 0.49 & ND & ND & 3.12 & 0.11 & ND & $\mathrm{ND}$ & ND & ND \\
\hline
\end{tabular}

${ }^{\mathrm{a}}$ Multinational manufacturer. ${ }^{\mathrm{b}}$ Regional manufacturer. ${ }^{\mathrm{c}}$ Local manufacturer. ${ }^{\mathrm{d}}$ Herbal practitioners. ${ }^{\mathrm{e}}$ Sample contaminated/total number of samples.

${ }_{\mathrm{f}}^{\mathrm{f}}$ Frequency of occurrence \% (number of samples containing a fungal species/total number of samples evaluated, \%). ${ }^{\mathrm{g}}$ Total incidence of species isolated\% (no. of isolates of the species/total no of isolates, \%). ${ }^{\mathrm{h}}$ Not detected.

TABLE 2: Fungal contamination of various manufacturing categories of triphala powder samples.

\begin{tabular}{lcccc}
\hline & $\begin{array}{c}\text { No. of } \\
\text { sample }\end{array}$ & $\begin{array}{c}\text { CFU } \\
\text { range }\end{array}$ & $\begin{array}{c}\text { Samples } \\
\text { contaminated } \\
(\%)\end{array}$ & $\begin{array}{c}\mathrm{CFU}>10^{3} \\
(\%)\end{array}$ \\
\hline $\begin{array}{l}\text { Total } \\
\text { collected }\end{array}$ & 60 & $10^{2}-10^{5}$ & 75 & 68.33 \\
$\begin{array}{l}\text { Multinational } \\
\text { Companies }\end{array}$ & 15 & $10^{2}-10^{5}$ & 73.33 & 66.66 \\
$\begin{array}{l}\text { Regional } \\
\text { manufacturer }\end{array}$ & 32 & $10^{2}-10^{5}$ & 78.12 & 75 \\
$\begin{array}{l}\text { Local } \\
\text { manufacturer }\end{array}$ & 9 & $10^{2}-10^{4}$ & 77.77 & 55.55 \\
$\begin{array}{l}\text { Herbal } \\
\text { Practitioners }\end{array}$ & 4 & $10^{3}-10^{4}$ & 50 & 50 \\
\hline
\end{tabular}

multinational manufacturers, $73 \%$ (11/15) of the samples were contaminated with 8 fungal species in the range of $10^{2}-$ $10^{5} \mathrm{CFU} / \mathrm{g}$ and about $66 \%$ of the samples were with CFU $>10^{3}$ spores/g. Aspergillus was the most dominant genus, representing 5 out of 9 isolated Aspergillus species. Among isolated fungi, $A$. niger was the most prevalent species, isolated from the $66.66 \%$ of the samples, followed by $A$. carbonarius (26.66\%), A. fumigatus (20\%), and A. nidulans (20\%) (Table 1). Other fungal species which were isolated from the samples of multinational manufacturers were A. luchuensis, A. flavus, Penicillium chrysogenum, and Fusarium sp., $6.66 \%$ each (Table 1).

In samples of regional manufacturers, about 78\% (25/32) of the samples were found to harbor 15 out of 16 isolated fungal species up to $10^{5} \mathrm{CFU} / \mathrm{g}$ and $75 \%$ of the samples with CFU $>10^{3}$ spores/g. Except $A$. wentii, all the species were present in one or other sample. Aspergillus group was detected as the most dominant genus with black Aspergilli as major contributors. A. niger was once again found as most dominant fungal species with frequency of occurrence of $59.37 \%$, followed by $A$. fumigatus (28.12\%), A. carbonarius, and $A$. luchuensis, $12.5 \%$ each. Other isolated fungal species were present in fewer samples only (Tables 1 and 2).

Samples collected from the local manufacturers were also found to harbor Aspergillus as major fungal group. About $78 \%$ of the samples were contaminated with 7 different fungal species in the range of $10^{2}-10^{4} \mathrm{CFU} / \mathrm{g}$ and $55 \%$ samples with fungal load of $>10^{3} \mathrm{CFU} / \mathrm{g}$. Prevalence of $A$. niger in $77 \%$ samples and maximum presence of fungal species like Curvularia lunata and Alternaria alternata were also recorded from the samples. While in case of samples collected from the herbal practitioners, 2 out of 4 were contaminated with 5 different fungal species. A. niger, A. flavus, and A. fumigatus were the most prevalent species (Tables 1 and 2).

In general, it was found that there was not much diversity in mycobiota of collected triphala powder samples at the genus level. Isolated fungal species belong to 7 different genera. A. niger was recorded as most dominant Aspergilli with $76.81 \%$ share among Aspergillus species. Among the different categories of triphala powder, samples of regional $(78.12 \%)$ and local manufacturer $(77.77 \%)$ were most contaminated but only $55.55 \%$ samples of local manufacturer have CFU $>10^{3}$ spores/g as compare to the samples of regional $(75 \%)$ and multinational manufacturers $(66.66 \%)$. The samples of regional manufacturer were found to harbor highest number 
TABLE 3: Relationship between the $\mathrm{pH}$ of triphala powder samples and fungal contamination.

\begin{tabular}{lcccccc}
\hline pH range (5\%) & $\begin{array}{c}\text { No. of samples } \\
(a / b)^{\mathrm{a}}\end{array}$ & $\mathrm{CFU}^{\mathrm{b}}$ range & $\begin{array}{c}\text { Species isolated } \\
c / d^{\mathrm{c}}\end{array}$ & $\begin{array}{c}\text { Dominant } \\
\text { species }\end{array}$ & $\begin{array}{c}\text { CFU > 10 } \\
(\%)^{\mathrm{d}}\end{array}$ & $\begin{array}{c}\text { Contaminated } \\
\text { samples }(\%)^{\mathrm{e}}\end{array}$ \\
\hline $3.50-3.60$ & $5 / 60$ & $10^{2}-10^{5}$ & $6 / 16$ & A. niger & 60 & 80 \\
$3.61-3.70$ & $25 / 60$ & $10^{3}-10^{5}$ & $13 / 16$ & A. niger & 80 & 88 \\
$3.71-3.80$ & $16 / 60$ & $10^{3}-10^{4}$ & $6 / 16$ & A. niger & 68.75 & 68.75 \\
$3.81-3.90$ & $3 / 60$ & $\leq 10^{3}$ & $4 / 16$ & A. niger & 33.33 & 33.33 \\
$3.91-4$ & $4 / 60$ & $\leq 10^{3}$ & $3 / 16$ & P. citrinum & 25 & 50 \\
$4.1-5$ & $5 / 60$ & $10^{2}-10^{3}$ & $7 / 16$ & A. niger & 60 & 80 \\
$5.1-7$ & $2 / 60$ & $\leq 10^{3}$ & $2 / 16$ & A. niger & 50 & 50 \\
\hline
\end{tabular}

${ }^{\mathrm{a}}$ Number of samples in $\mathrm{pH}$ range/total number of samples. ${ }^{\mathrm{b}}$ Colony forming unit. ${ }^{\mathrm{c}}$ Number of species isolated from the samples of $\mathrm{pH}$ range/total number of species isolated. ${ }^{\mathrm{d}}$ Samples having $\mathrm{cfu}>10^{3} /$ total number of samples in $\mathrm{pH}$ range, \%. ${ }^{\mathrm{e}}$ Number of samples contaminated in $\mathrm{pH}$ range/total number of sample in $\mathrm{pH}$ range, \%.

TABLE 4: Relationships between the percent moisture contents of triphala powder samples and fungal contamination.

\begin{tabular}{lcccccc}
\hline Moisture range \% & $\begin{array}{c}\text { No. of samples } \\
(a / b)^{\mathrm{a}}\end{array}$ & $\mathrm{CFU}^{\mathrm{b}}$ range & $\begin{array}{c}\text { Species isolated } \\
(c / d)^{\mathrm{c}}\end{array}$ & $\begin{array}{c}\text { Dominant } \\
\text { species }\end{array}$ & $\begin{array}{c}\text { CFU }>10^{3} \\
(\%)^{\mathrm{d}}\end{array}$ & $\begin{array}{c}\text { Contaminated } \\
\text { samples }(\%)^{\mathrm{e}}\end{array}$ \\
\hline $4-5$ & $5 / 60$ & $10^{3}-10^{4}$ & $5 / 16$ & A. niger & 66.66 & 80 \\
$5-6$ & $11 / 60$ & $10^{3}-10^{5}$ & $6 / 16$ & A. niger & 54.54 & 54.54 \\
$6-7$ & $9 / 60$ & $10^{2}-10^{4}$ & $6 / 16$ & A. niger & 55.55 & 66.66 \\
$7-8$ & $7 / 60$ & $10^{3}-10^{5}$ & $7 / 16$ & A. niger & 85.71 & 71.42 \\
$8-9$ & $14 / 60$ & $10^{2}-10^{5}$ & $7 / 16$ & A. niger & 78.71 \\
$>9$ & $14 / 60$ & $10^{2}-10^{5}$ & $11 / 16$ & A. niger & 71.42 & 85.71 \\
\hline
\end{tabular}

${ }^{a}$ Number of samples in percent moisture range/total number of samples. ${ }^{b}$ Colony forming unit. ${ }^{c}$ Number of species isolated from the samples of the percent moisture range/total number of species isolated. ${ }^{\mathrm{d}}$ Samples having $\mathrm{cfu}>10^{3} /$ total number of samples in the percent moisture range, \%. ${ }^{\mathrm{e}}$ Number of samples contaminated in percent moisture range/total number of samples in the percent moisture range, $\%$.

(15) of fungal species, whereas samples collected from the herbal practitioners were with minimum (4) fungal species and only $50 \%$ of the samples with CFU $>10^{3}$ spores/g.

3.2. $p H$ versus Fungal Contamination. Table 3 shows the relationship between $\mathrm{pH}$ of the samples ( $5 \%$ suspension) and rate of fungal contamination. It was found that $\mathrm{pH}$ of collected samples ranges from 3.50 to 7.0. The majority of the samples were below $\mathrm{pH}$ 4. Maximum number of samples (25/60) lies in the $\mathrm{pH}$ range of 3.61-3.70 and the minimum number of samples $(2 / 60)$ in a $\mathrm{pH}$ range of $5-7$ on the $\mathrm{pH}$ scale. It was found that samples with $\mathrm{pH}$ above 3.81 were less contaminated as compared to the samples below this $\mathrm{pH}$ range, although no significant correlation was observed between $\mathrm{pH}$ values and fungal contamination $(r=-0.307 ; P>0.05)$. The high rate of contamination (88\%) was observed in the samples of $\mathrm{pH}$ range 3.61-3.70 with isolation of 13 fungal species and $80 \%$ of samples with fungal load of $>10^{3} \mathrm{CFU} / \mathrm{g}$. A. niger was recorded as the most dominant fungal species in all $\mathrm{pH}$ ranges, except $\mathrm{pH}$ range of 3.91-4 where Penicillium citrinum was the most dominant fungal species.

3.3. Percent Moisture Content versus Fungal Contamination. The percent moisture content was found to govern the extent of contamination and species diversity in triphala powder samples. As it is evident from Table 4, the samples with higher level of percent moisture content were more contaminated than the samples with less moisture content. A strong positive correlation $(r=0.868 ; P<0.05)$ was observed between the percent moisture content and the species. It was found that samples with more than $7 \%$ moisture content were more contaminated $(7-8=85.71 \% ; 8-9=78.57 \% ;>9=85.71 \%)$ and more than $70 \%$ of these samples were with fungal load of $>10^{3} \mathrm{CFU} / \mathrm{g}$ than samples with moisture range of $<7 \%$. Among isolated fungal species, Aspergillus niger was detected as the most dominant species in all ranges of percent moisture content.

3.4. Storage Time versus Fungal Contamination. Out of 60 samples, only on the packs of 41 samples, date of manufacturing was mentioned. The time period between date of Mfg. and date of collection was considered as storage time and all the results were drawn on the same basis.

As it is evident from Table 5, the high rate of contamination was observed in the storage range of 4-5 (90\%) and 10$11(100 \%)$ months of storage period and minimum in storage range of 6-7 (66.66\%) and $>12(69.23 \%)$ months period of storage. No significant correlation was observed between storage period, fungal diversity, and fungal load. But strong positive correlation was observed between the increased percent moisture content and fungal contamination irrespective of storage period, that is, samples of storage period ranges with less moisture content were less contaminated (6-7 and $>12$ months storage period range) and samples of storage period with high moisture content were more contaminated $(r=0.950 ; P<0.05)$. Again, Aspergillus niger was recorded as 
TABLE 5: Relationship among storage time, percent moisture content, and fungal contamination of triphala powder samples.

\begin{tabular}{lccccccc}
\hline $\begin{array}{l}\text { Storage period } \\
\text { (Months) }\end{array}$ & $\begin{array}{c}\text { Mean percent } \\
\text { moisture (\%) }\end{array}$ & $\begin{array}{c}\text { No. of samples } \\
(a / b)^{\mathrm{a}}\end{array}$ & $\begin{array}{c}\mathrm{CFU}^{\mathrm{b}} \\
\text { range }\end{array}$ & $\begin{array}{c}\text { Species isolated } \\
(c / d)^{\mathrm{c}}\end{array}$ & $\begin{array}{c}\text { Dominant } \\
\text { species }\end{array}$ & $\begin{array}{c}\text { CFU }>10^{3} \\
(\%)^{\mathrm{d}}\end{array}$ & $\begin{array}{c}\text { Contaminated } \\
\text { samples }(\%)^{\mathrm{e}}\end{array}$ \\
\hline $2-3$ & 7.71 & $6 / 41$ & $10^{2}-10^{5}$ & $6 / 16$ & A. niger & 66.66 & 83.33 \\
$4-5$ & 7.65 & $10 / 41$ & $10^{3}-10^{5}$ & $9 / 16$ & A. niger & 80 & 90 \\
$6-7$ & 5.05 & $3 / 41$ & $\leq 10^{4}$ & $4 / 16$ & A. niger & 66.66 & 66.66 \\
$8-9$ & 7.06 & $7 / 41$ & $10^{3}-10^{5}$ & $6 / 16$ & A. niger & 85.71 & 85.71 \\
$10-11$ & 8.42 & $2 / 41$ & $10^{3}-10^{5}$ & $5 / 16$ & A. niger & 100 & 100 \\
$>12$ & 5.96 & $13 / 41$ & $10^{3}-10^{4}$ & $9 / 16$ & A. niger & 69.23 & 69.23 \\
\hline
\end{tabular}

${ }^{\mathrm{a}}$ Number of samples in storage period/total number of samples. ${ }^{\mathrm{b}}$ Colony forming unit. ${ }^{\mathrm{c}}$ Number of species isolated from the samples of storage period/total number of species isolated. ${ }^{\mathrm{d}}$ Samples having cfu $>10^{3} /$ total samples present in storage period, $\% .{ }^{\mathrm{e}}$ Number of samples contaminated in storage period/total number of samples in storage period, \%.

the most dominant fungal species, isolated from the samples of all storage period ranges.

\section{Discussion}

4.1. Mycobiota of Triphala Powder. There are only few reports available on the microbial contamination of triphala powder, the majority of them dealing with bacterial contamination. However, plenty of reports are available on the fungal contamination of herbal drugs. In our study, we isolated 16 fungal species belonging to 7 genera from 60 diverse types of triphala powder samples. Occurrence of Aspergillus was observed in almost all of the samples. These results were in accordance with the observations of Gautam and Bhadauria [17], which is the only report on the fungal contamination of triphala powder. Beside other isolated fungi, two species of Aspergillus, that is, A. carbonarius and $A$. wentii, were not reported earlier from triphala powder. Several authors also reported the Aspergillus as the most dominant genus and A. niger as most prevalent species in herbal drugs samples $[5,8,9,12$, 14, 25-31]. This is in agreement with our findings. This high incidence of black aspergilli can be justified on the basis of the black color of the spores that apparently provide protection from sunlight and UV rays during sun drying $[32,33]$.

In general, the occurrence of both types of moulds, that is, field and storage fungi, was observed in our study. Isolated species of Alternaria, Fusarium, and Curvularia belong to field fungi and generally infest the plants during the field stage, that is, during growth, development, and harvesting, whereas, frequently occurring spp. of Aspergillus and Penicillium, reported as storage fungi, infest products during storage. This may be the probable reason of the high occurrence of Aspergilli in our samples; secondly, this high occurrence of Aspergilli and low frequency or absence of other fungi may be due to high phenolic contents of triphala powder.

Reports of various researchers also approved the inhibitory effect of phenolics against pathogenic, field fungi, and ineffectiveness in controlling the growth of storage fungi, especially Aspergillus group [34-37]. These reports are in agreement with our results, where about $96 \%$ isolates were of Aspergillus group.

A variation in fungal diversity and fungal load was observed in between the triphala powder of various manufacturing categories. Although, all the categories showed almost equal percentage of fungal contamination but more than $75 \%$ samples of the regional manufacturers were loaded with fungal count more than the specified limit of $10^{3} \mathrm{CFU} / \mathrm{g}$ for herbal drugs of internal uses [18]. This may be due to the violation of guidelines laid down in the Ayurvedic pharmacopeia of India/WHO by regional manufacturers during manufacturing, because of the marketing of their products in local markets only. Triphala powder samples of local manufacturer and herbal practitioners were found less contaminated in comparison to the samples of other categories. This low contamination may be because of the limited production of formulation by local manufacturers and herbal practitioners as per the local demand.

The presence of $A$. carbonarius and $A$. niger in high amount is alarming, as it has been well established that $A$. carbonarius is a potent producer of ochratoxin followed by A. niger [33, 38-42].

4.2. $\mathrm{pH}$ versus Fungal Contamination. $\mathrm{pH}$ of a substrates and types of substrates were reported to influence the fungal diversity in nature [43]. During present investigation, samples with a low $\mathrm{pH}$ range (3.50 to 4.0) were found to harbor a good number of fungi. Reports of 2010 and 2011 indicate that low $\mathrm{pH}$ (acidic range $\mathrm{pH} 4-6$ ) favors good fungal growth and recolonization of fungi in soil $[43,44]$. Low $\mathrm{pH}$ was also found to favor mycelial development of Trichoderma harzianum [45]. Trends of these findings authenticate our results, indicating high fungal contamination in samples of triphala powders with low $\mathrm{pH}$ as compare to samples with higher $\mathrm{pH}$ value. Aspergillus was recorded as the most dominant genus in samples of all $\mathrm{pH}$ ranges; this can be attributed to the ability of the Aspergilli to grow in a wide range of $\mathrm{pH}$. Wheeler et al. [46] observed that Aspergillus species are more tolerant to alkaline $\mathrm{pH}$, while Penicillium are more tolerant to acidic $\mathrm{pH}$. This is in accordance with our findings where A. niger and Penicillium were recorded as the most dominant fungal species in the $\mathrm{pH}$ ranges of 3.50 to 7.0 and 3.91 to 4.0, respectively. Singh et al. [12], Mandeel [27], and Mishra et al. [31] isolated the various fungal species from the spices and crude plant material with very high moisture contents ranging from 9 to $63 \%$ and tried to correlate fungal diversity and fungal load with $\mathrm{pH}$ of the samples. 
4.3. Percent Moisture Content versus Fungal Contamination. Being a plant based formulation; triphala powder is prone to fungal contamination. Various stages during processing of formulation like harvesting, drying, grinding, and storage play certain role in contamination of the product. Drying and storage are the two important steps that determine the rate of contamination. Any availability of sufficient moisture in stored material results into microbial contamination. Water availability is the key factor in controlling contamination of medicinal plant material. Higher moisture content makes a substrate favorable for fungal invasion. In the present study triphala powder samples with higher moisture content were more contaminated as compared to the samples with less moisture content secondly, a gradual increase in fungal diversity and percentage of samples with CFU $>10^{3} / \mathrm{g}$ was also observed. This is in accordance with the findings of Oyebanji and Efiuvwevwere [47] and Quezada et al. [48] who reported a gradual increase in fungal load and diversity with increase in moisture content of stored maize sample. Moisture content along with substrate type and nutrient availability and presence of secondary metabolite also affect the extent of fungal contamination [12, 27, 31]. It is well established that the diversity and overall fungal load (CFU/g) vary with the $a_{w}$ value of the samples $[49,50]$.

4.4. Storage Time versus Fungal Contamination. Duration of the storage has been reported to influence the level of fungal contamination of stored plant commodities [51]. It was observed that storage period is not the sole factor in determining the fungal load and diversity; it is coupled with moisture content of the samples. Triphala powder samples with a storage period of more than one year (from manufacturing date) were less contaminated due to critically low moisture content $(5.96 \%)$ and samples with less than 6 months storage period were more contaminated due to high moisture content $(>7 \%)$. Total absences of fungal contaminants were observed in very old sealed expiry dated samples with very low moisture content $(<5 \%)$. This again proves that storage period is not the sole determining factor. These findings are also in accordance with the Oyebanji and Efiuvwevwere [47] and Quezada et al. [48]. who reported a gradual increase in fungal load and fungal diversity, while increasing the storage time along with moisture content.

\section{Conclusion}

A wide range of fungal contaminants were discovered from the triphala powder. The rate and extent of contamination was strongly influenced by the $\mathrm{pH}$, moisture content, and storage condition of the product. In phenolics rich triphala powder, storage fungi were in dominance as compared to field and other fungi. Our data also presented the variation in the rate of contamination between products of different manufacturers. This high contamination may hit the global market of triphala powder, which will be a setback for Indian herbal Industry which is facing strong competition from Chinese herbal Industries. Therefore, Indian herbal industries need to strengthen their quality control measures, especially during storage and processing with controlled moisture content, so that microbial contamination can be reduced to globally expectable limit.

\section{Conflict of Interests}

Authors declare that there is no conflict of interest.

\section{Acknowledgment}

The authors are grateful to the School of Studies in Botany, Jiwaji University, Gwalior (India), for providing the necessary facilities to carry out this study.

\section{References}

[1] M. Gupta, "Therapeutic uses of the polyherbal drug Triphala in geriatric diseases," International Journal of Pharma and Bio Sciences, vol. 1, no. 2, pp. 1-13, 2010.

[2] P. K. Mukherjee, S. Rai, S. Bhattacharyya et al., "Clinical study of "Triphala": a well known phytomedicine from India," Iranian Journal of Pharmacology and Therapeutics, vol. 5, no. 1, pp. 51$54,2006$.

[3] G. H. Naik, K. I. Priyadarsini, and H. Mohan, "Free radical scavenging reactions and phytochemical analysis of triphala, an ayurvedic formulation," Current Science, vol. 90, no. 8, pp. 11001105,2006

[4] M. Hashimoto and Y. Nakajim, "Antiobesity agents, alpha amylase inhibitors, lipase inhibitors, foods and beverages containing plant extracts," Japanese Kokai Tokkyo Koho, vol. 9, pp. 227-398, 1997.

[5] H. Hitokoto, S. Morozumi, T. Wauke, S. Sakai, and H. Kurata, "Fungal contamination and mycotoxin detection of powdered herbal drugs," Applied and Environmental Microbiology, vol. 36, no. 2, pp. 252-256, 1978.

[6] H. K. Choursia, "Aflatoxin contamination in drug yielding plants," Journal of Indian Botanical Society, vol. 69, pp. 281-283, 1990.

[7] A. K. Roy and H. K. Chourasia, "Mycoflora, mycotoxin producibility and mycotoxins in traditional herbal drugs from India," Journal of General and Applied Microbiology, vol. 36, no. 5, pp. 295-302, 1990.

[8] H. K. Chourasia, "Mycobiota and mycotoxins in herbal drugs of Indian pharmaceutical industries," Mycological Research, vol. 99, no. 6, pp. 697-703, 1995.

[9] M. O. Efuntoye, "Fungi associated with herbal drug plants during storage," Mycopathologia, vol. 136, no. 2, pp. 115-118, 1996.

[10] M. Halt, "Moulds and mycotoxins in herb tea and medicinal plants," European Journal of Epidemiology, vol. 14, no. 3, pp. 269274, 1998.

[11] A. Bugno, A. B. A. Adriana, T. C. Pereira, T. D. J. Andreoli Pinto, and M. Sabino, "Occurrence of toxigenic fungi in herbal drugs," Brazilian Journal of Microbiology, vol. 37, no. 1, pp. 47-51, 2006.

[12] P. Singh, B. Srivastava, A. Kumar, and N. K. Dubey, "Fungal contamination of raw materials of some herbal drugs and recommendation of Cinnamomum camphora oil as herbal fungitoxicant," Microbial Ecology, vol. 56, no. 3, pp. 555-560, 2008.

[13] A. K. Gautam and R. Bhadauria, "Occurrences of toxigenic moulds and mycotoxins in Ayurvedic medicine Trifla churna," Journal of Mycology and Plant Pathology, vol. 38, no. 3, pp. 664666, 2008. 
[14] A. K. Gautam and R. Bhadauria, "Mycoflora and mycotoxins in some important stored crude and powdered herbal drugs," Biological Forum, vol. 1, no. 1, pp. 1-7, 2009.

[15] G. R. Dutta and A. K. Roy, "Mycoflora associated with Strychnos seeds and deterioration of their active principles under storage," Indian Phytopathology, vol. 40, pp. 520-524, 1987.

[16] M. Peraica, B. Radić, A. Lucić, and M. Pavlović, “Toxic effects of mycotoxins in humans," Bulletin of the World Health Organization, vol. 77, no. 9, pp. 754-766, 1999.

[17] A. K. Gautam and R. Bhadauria, "Diversity of fungi and mycotoxins associated with stored Triphala churn and its ingredients," Journal of Biological Sciences, vol. 11, no. 3, pp. 226-235, 2011.

[18] World Health Organization, "Quality control methods for medicinal plant materials revised draft update," Working Document QAS/05.131/Rev.1, 2005.

[19] C. Thom and K. B. Raper, A Manual of Aspergilli, Willima and Willikins Company, New York, NY, USA, 1945.

[20] J. C. Gilman, A Manual of Soil Fungi, Iowa State College Press, Ames, Iowa, USA, 2nd edition, 1971.

[21] H. L. Barnett, Illustrated Genera of Imperfect Fungi, Burgess Publishing Company, Minnesota, Minn, USA, 1969.

[22] M. Jamaluddin, G. Goswami, and B. M. Ojha, Fungi of India 1989-2001, Scientific Publisher, Jodhpur, India, 2004.

[23] R. A. Samson, S. Hong, S. W. Peterson, J. C. Frisvad, and J. Varga, "Polyphasic taxonomy of Aspergillus section Fumigati and its teleomorph Neosartorya," Studies in Mycology, vol. 59, pp. 147203, 2007.

[24] R. A. Samson, P. Noonim, M. Meijer, J. Houbraken, J. C. Frisvad, and J. Varga, "Diagnostic tools to identify black aspergilli," Studies in Mycology, vol. 59, pp. 129-145, 2007.

[25] A. A. K. Abou-Arab, M. S. Kawther, M. E. El Tantawy, R. I. Badeaa, and N. Khayria, "Quantity estimation of some contaminants in commonly used medicinal plants in the Egyptian market," Food Chemistry, vol. 67, no. 4, pp. 357-363, 1999.

[26] I. Rizzo, G. Vedoya, S. Maurutto, M. Haidukowski, and E. Varsavsky, "Assessment of toxigenic fungi on Argentinean medicinal herbs," Microbiological Research, vol. 159, no. 2, pp. 113-120, 2004.

[27] Q. A. Mandeel, "Fungal contamination of some imported spices," Mycopathologia, vol. 159, no. 2, pp. 291-298, 2005.

[28] A. Kumar, R. Shukla, P. Singh, and N. K. Dubey, "Biodeterioration of some herbal raw materials by storage fungi and aflatoxin and assessment of Cymbopogon flexuosus essential oil and its components as antifungal," International Biodeterioration and Biodegradation, vol. 63, no. 6, pp. 712-716, 2009.

[29] A. Chukwudi, "Fungal contamination of powdered herbal drugs sold in parts of Enugu state, Southeast, Nigeria," Plant Product Research Journal, vol. 14, pp. 46-50, 2010.

[30] A. Tahir and M. Aftab, "Microbial assessment of herbal drugs available in local market of Lahore," Canadian Journal of Applied Science, vol. 1, no. 3, pp. 97-103, 2011.

[31] P. K. Mishra, R. Shukla, P. Singh, B. Prakash, and N. K. Dubey, "Antifungal and antiaflatoxigenic efficacy of Caesulia axillaris Roxb. essential oil against fungi deteriorating some herbal raw materials, and its antioxidant activity," Industrial Crops and Products, vol. 36, no. 1, pp. 74-80, 2012.

[32] J. I. Pitt and A. D. Hocking, Fungi and Food Spoilage, Blackie Academics \& Professional, London, UK, 1997.

[33] S. M. Romero, R. M. Comerio, G. Larumbe, A. Ritieni, G. Vaamonde, and V. Fernández Pinto, "Toxigenic fungi isolated from dried vine fruits in Argentina," International Journal of Food Microbiology, vol. 104, no. 1, pp. 43-49, 2005.

[34] K. Sinha and P. Singh, "Effects of some phenolics on aflatoxin production and growth of Aspergillus parasiticus," Indian Phytopathology, vol. 34, pp. 530-531, 1981.

[35] M. M. Cowan, "Plant products as antimicrobial agents," Clinical Microbiology Reviews, vol. 12, no. 4, pp. 564-582, 1999.

[36] J. D. Miller, D. A. Fielder, P. F. Dowd, R. A. Norton, and F. W. Collins, "Isolation of 4-acetyl-benzoxazolin-2-one (4-ABOA) and diferuloylputrescine from an extract of gibberella ear rotresistant corn that blocks mycotoxin biosynthesis, and the insect toxicity of 4-ABOA and related compounds," Biochemical Systematics and Ecology, vol. 24, no. 7-8, pp. 647-658, 1996.

[37] S. Samapundo, B. de Meulenaer, D. Osei-Nimoh, Y. Lamboni, J. Debevere, and F. Devlieghere, "Can phenolic compounds be used for the protection of corn from fungal invasion and mycotoxin contamination during storage?" Food Microbiology, vol. 24, no. 5, pp. 465-473, 2007.

[38] J. Téren, J. Varga, Z. Hamari, E. Rinyu, and F. Kevei, "Immunochemical detection of ochratoxin A in black Aspergillus strains," Mycopathologia, vol. 134, no. 3, pp. 171-176, 1996.

[39] C. N. Heenan, K. J. Shaw, and J. I. Pitt, "Ochratoxin A production by Aspergillus carbonarius and A. niger isolates and detection using coconut cream agar," Journal of Food Mycology, vol. 1, pp. 67-72, 1998.

[40] M. H. Taniwaki, J. I. Pitt, A. A. Teixeira, and B. T. Iamanaka, "The source of ochratoxin A in Brazilian coffee and its formation in relation to processing methods," International Journal of Food Microbiology, vol. 82, no. 2, pp. 173-179, 2003.

[41] S. L. L. Leong, A. D. Hocking, and E. S. Scott, "Effect of temperature and water activity on growth and ochratoxin $\mathrm{A}$ production by Australian Aspergillus carbonarius and A. niger isolates on a simulated grape juice medium," International Journal of Food Microbiology, vol. 110, no. 3, pp. 209-216, 2006.

[42] L. Alborch, M. R. Bragulat, M. L. Abarca, and F. J. Cabañes, "Effect of water activity, temperature and incubation time on growth and ochratoxin A production by Aspergillus niger and Aspergillus carbonarius on maize kernels," International Journal of Food Microbiology, vol. 147, no. 1, pp. 53-57, 2011.

[43] J. Rousk, P. C. Brookes, and E. Bååth, "Investigating the mechanisms for the opposing $\mathrm{pH}$ relationships of fungal and bacterial growth in soil," Soil Biology and Biochemistry, vol. 42, no. 6, pp. 926-934, 2010.

[44] G. Bárcenas-Moreno, J. Rousk, and E. Bååth, "Fungal and bacterial recolonisation of acid and alkaline forest soils following artificial heat treatments," Soil Biology and Biochemistry, vol. 43, no. 5, pp. 1023-1033, 2011

[45] M. A. Moreno-Mateos, J. Delgado-Jarana, A. C. Codón, and T. Benítez, "pH and Pacl control development and antifungal activity in Trichoderma harzianum," Fungal Genetics and Biology, vol. 44, no. 12, pp. 1355-1367, 2007.

[46] K. A. Wheeler, B. F. Hurdman, and J. I. Pitt, "Influence of pH on the growth of some toxigenic species of Aspergillus, Penicillium and Fusarium," International Journal of Food Microbiology, vol. 12, no. 2-3, pp. 141-149, 1991.

[47] A. O. Oyebanji and B. J. O. Efiuvwevwere, "Growth of spoilage mould and aflatoxin B1 production in naturally contaminated or artificially inoculated maize as influenced by moisture content under ambient tropical condition," International Biodeterioration and Biodegradation, vol. 44, no. 4, pp. 209-217, 1999.

[48] M. Y. Quezada, J. Moreno, M. E. Vázquez, M. Mendoza, A. Méndez-Albores, and E. Moreno-Martínez, "Hermetic storage 
system preventing the proliferation of Prostephanus truncatus Horn and storage fungi in maize with different moisture contents," Postharvest Biology and Technology, vol. 39, no. 3, pp. 321326, 2006.

[49] M. V. Copetti, B. T. Iamanaka, J. C. Frisvad, J. L. Pereira, and M. H. Taniwaki, "Mycobiota of cocoa: from farm to chocolate," Food Microbiology, vol. 28, no. 8, pp. 1499-1504, 2011.

[50] S. Marín, C. Colom, V. Sanchis, and A. J. Ramos, "Modelling of growth of aflatoxigenic A. flavus isolates from red chilli powder as a function of water availability," International Journal of Food Microbiology, vol. 128, no. 3, pp. 491-496, 2009.

[51] A. N. Kaaya and W. Kyamuhangire, "The effect of storage time and agroecological zone on mould incidence and aflatoxin contamination of maize from traders in Uganda," International Journal of Food Microbiology, vol. 110, no. 3, pp. 217-223, 2006. 

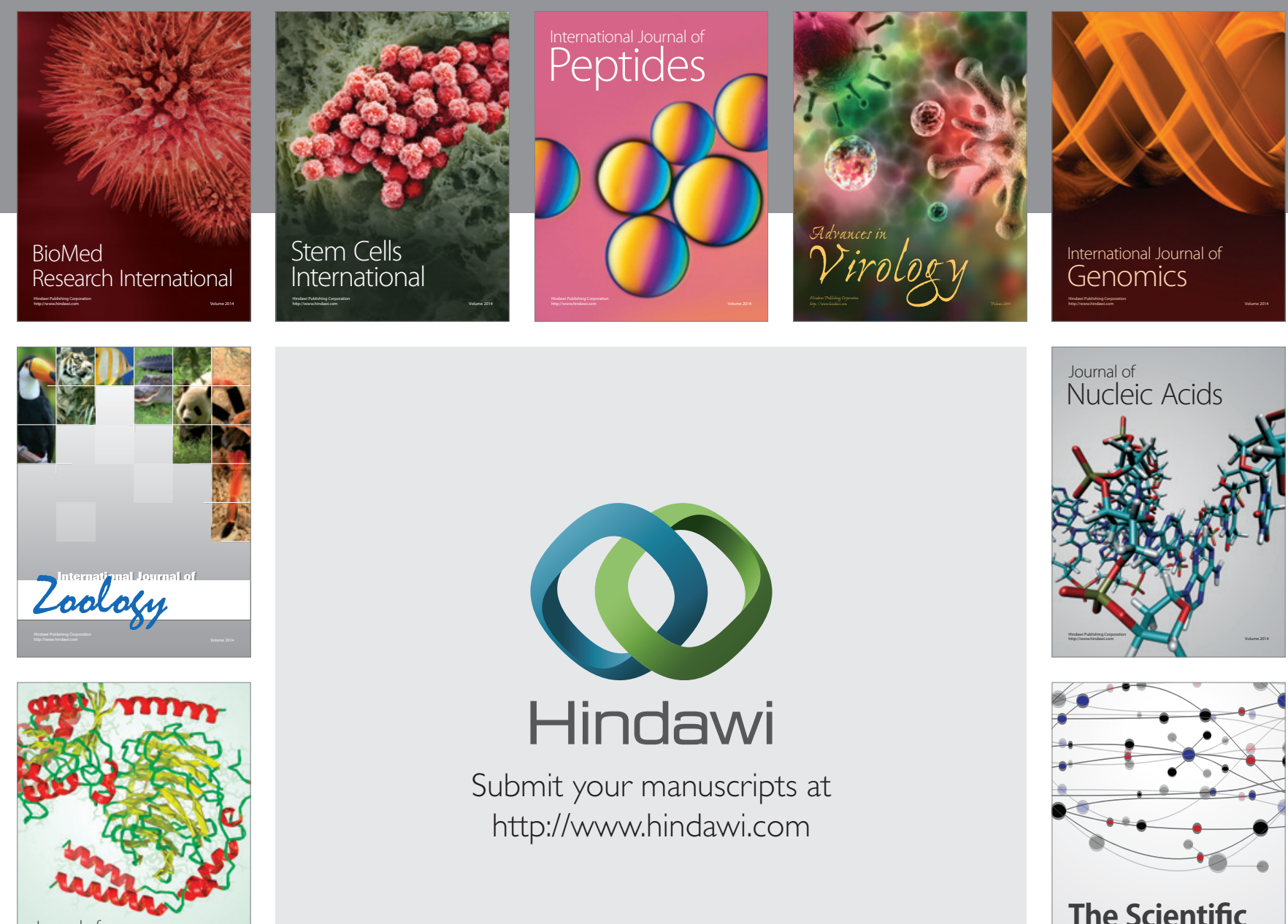

Submit your manuscripts at

http://www.hindawi.com

Journal of
Signal Transduction
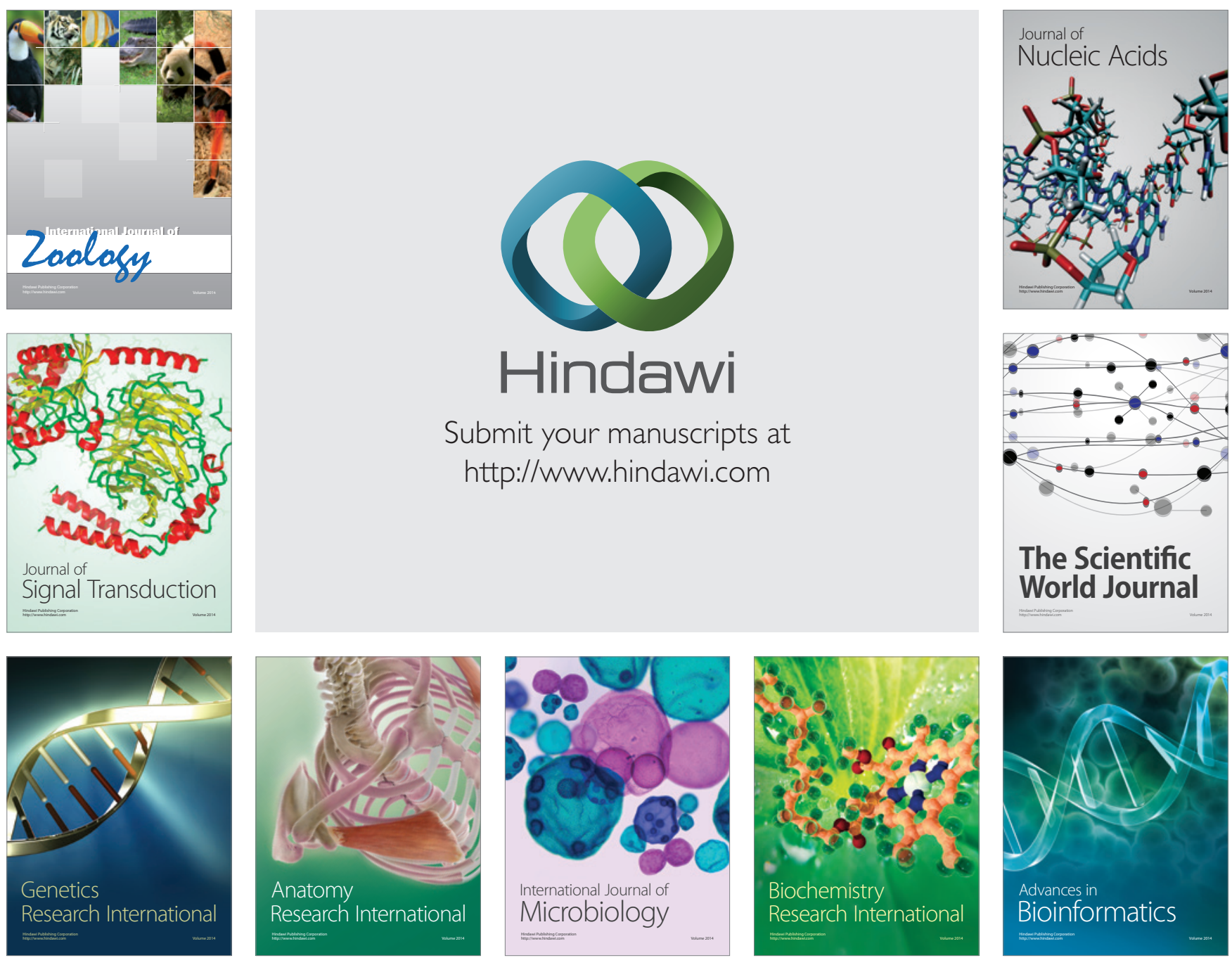

The Scientific World Journal
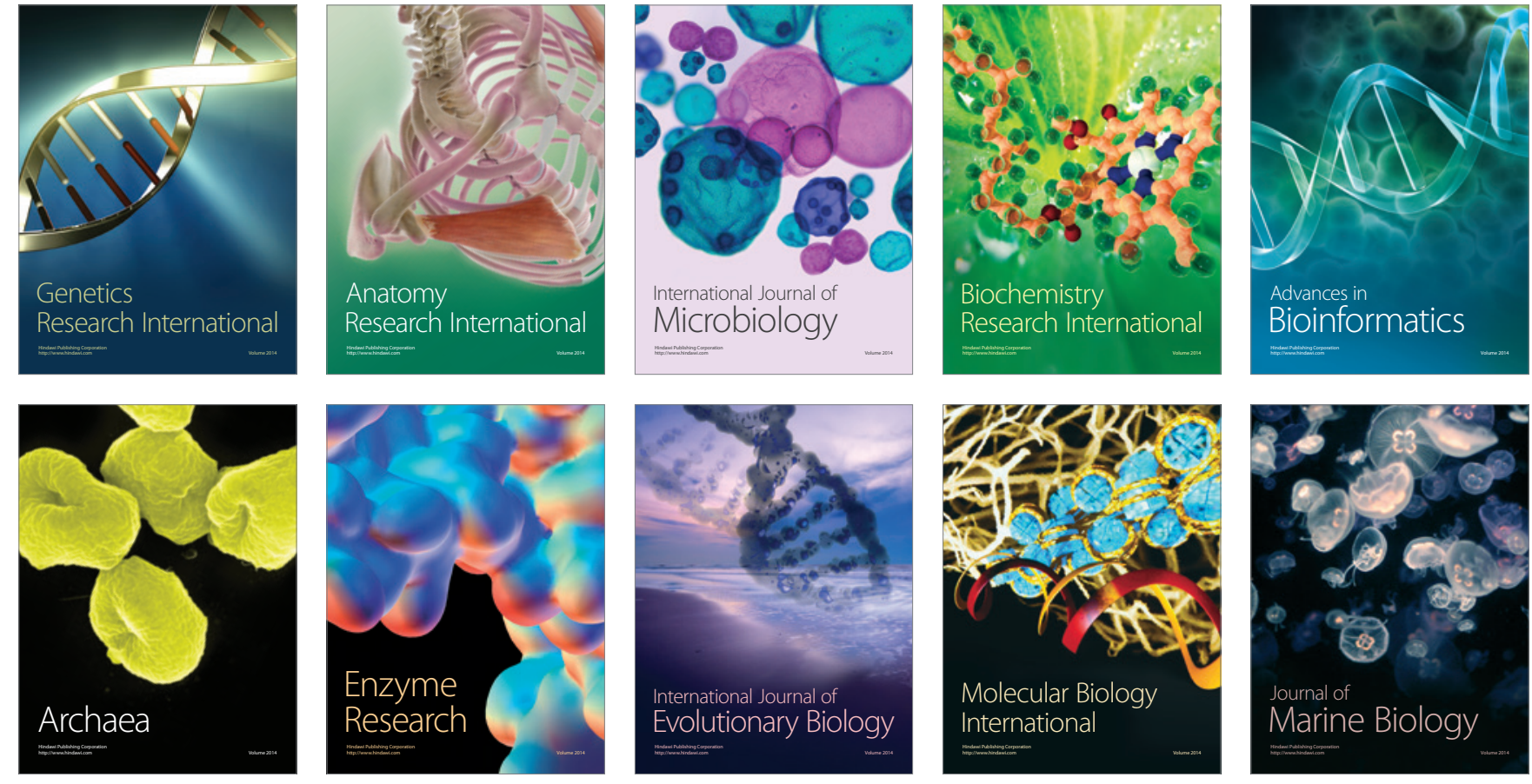